\title{
The Evaluation of Graduate's Employability in Application-oriented
}

\author{
Undergraduate \\ Ling Yan ${ }^{1,}$ a, Tao Yang1, b \\ ${ }^{1}$ School of Management, Tianjin University of Technology, Tianjin 300384, China. \\ alingyantj@163.com, btmac386906713@163.com
}

Keywords: application-oriented undergraduate; employability; evaluation index.

\begin{abstract}
In order to solve the structural conflict in the employment of graduate and improve the quality of talent training. On the basis of literature analysis and expert-group discussion, according to the analysis of the practice ability of professional in international industry associations, taking cost engineering as an example, the index system of employability evaluation of graduate is constructed, and divided into professional ability, learning ability, expression ability and professional quality. The results provide the alternative evaluation index and evaluation method for the cultivation of applied talents in colleges.
\end{abstract}

\section{Introduction}

The employment of college graduates in China presents a dilemma caused by structural contradiction, the main reason is that the mismatch between the cultivation of college graduate and the demand for human resources structure of enterprise [1]. To solve the structural contradiction of employment, it is necessary to promote the modern vocational education system which is employment-oriented [2]. Application-oriented undergraduate is the most important part of talents training in modern vocational education system, which is a kind of higher professional education differing from research-oriented undergraduate education [3], this mode of talents training must highlight the employment-oriented, ensuring that applicable talents can be consistent with social demands to deal with the structural contradiction in college graduates' employment. In order to improve the quality of undergraduate to meet the capacity requirements of employers, application-oriented colleges in China begin to explore new talents training mode of higher professional education.

However, because of ignoring the diverse, applied, composite position requirements faced by the application-oriented graduates in the process of practice in the future, even the students have the professional competence, but may not be able to meet the employability required by social and industry. Therefore, it is necessary to establish a reasonable evaluation index or evaluation method of application-oriented graduates' employability, which facilitates the evaluation, diagnose, feedback and suggestions for whether the graduates can meet the competency standards required by the position.

Based on this, taking the cost engineering of application-oriented undergraduate for an example, through literature analysis to establish the evaluation model of employability and achieve the 
evaluation of employability to guarantee the quality of graduates, cultivating the applied and compound talents with high quality to meet social and industry demands and providing the evidence for structural contradiction of employment and the competence standard available for the cultivation of application-oriented talents.

\section{Literature review}

The concept of employability originated in Britain in the 20th century, the former Department for Education and Employment (DFEE) in UK and International Labor Organization (ILO), point out that employability is the ability that individuals obtain and maintain employment, namely, the ability to make progress and deal with changes in work. Overtoom thinks that employability is not a specific work ability, but the ability related to all industries on the transverse section and all jobs in vertical direction [4]. Since the employability was introduced, researchers studied it from different perspectives, but all were built around skills collection of various abilities, their research were divided into three general categories below:

a) Employability is divided into three levels [5, 6]: The ability to gain initial employment, the ability to maintain employment, the ability to obtain a new employment opportunity if necessary. From the perspective of the initial employment, Xiong suggested that working ability, honesty, team work and innovation were important components of employability [7]. From a social capital perspective, Fugate, Huang, etc. expanded the employability, arguing that employability is defined as an ability to identify job opportunities and access to work for college students in employment and entrepreneurship, consisting of the intersection of career recognition, individual adaptability, social capital and human capital [8].

b) Employability is the embodiment of adaptive individual differences and how individuals realize the effective interaction between employability with the environment. Based on this, the comprehensive employability [9] was proposed, including personal skills, happiness, job search, suitability and other individual factors, also including work culture and availability of resources and external factors influencing the employment of individuals [10].Therefore, whether college students can obtain or increase employability depended on the collection of the knowledge, skills and personality traits, including technical skills, communication skills, personal property, interpersonal skills and team skills [11].

c) Some scholars specially emphasized that employability consisted of general ability needed for a job, expertise and knowledge learning skills [12]. From a personal point of view of employment, Vander suggested that employability was developed based on the learning ability, relevant to profession and embedded in the individual, making individuals acquire, retain and use certain qualifications or ability to deal with the changing labor market behavior [13].

The objective of applied-oriented undergraduate was to cultivate multi-level and multi-type of applied senior engineering and technical talents which had practical ability, innovative spirit, high comprehensive quality, meeting the diversified demand of economic and social development [14]. Therefore, simply learning from predecessors' research results of the characteristics items of college students' employability cannot very well solve the evaluation of employability of applied-oriented undergraduate, it is necessary to take deep and balanced consideration from the aspect of professional ability and comprehensive quality. 


\section{The selection of evaluation index system of graduates' employability in cost engineering}

The practice of the cost engineering professional included the cost and contract consulting work from decision-making, design, bidding to contract management in the whole construction process. The cost engineering is a diversified and multi-function role, the characteristic of the professional competency was applied and composite. On this basis, the famous international industry associations, such as the Royal institution of chartered Surveyor (RICS), Pacific Association of Quantity Surveyors (PAQS) and the institution of higher education jointly formulated the professional competency standard required for industry market [15, 16, 17]. Using the layered capability management thoughts, the standard formulated the basic capability, core capability and expert capability. With the help of professional certification system to guide the cultivation of professional talents of quantity surveying in colleges, ensuring to meet the requirement for different levels of professional ability in industry market, as shown in table 1 [18].

Table 1 Competency standards of international industry association on quantity surveying

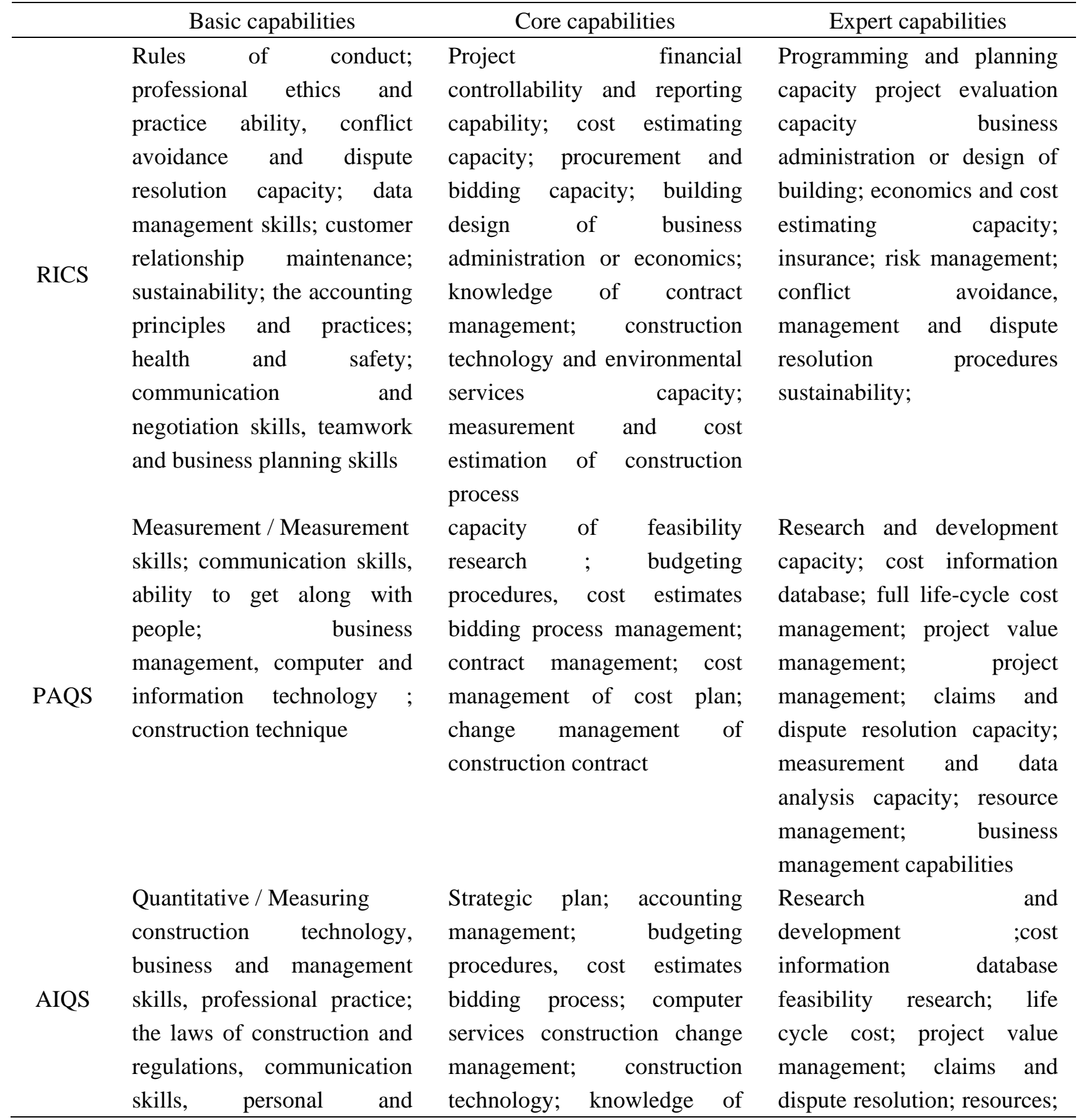


interpersonal skills, government system and legal computer and information technology business management project management project risk management;

It can be seen that the requirements of basic capability mostly emphasize on graduates' professional ethics, communication skills, personal qualities and interpersonal skills; the core capability emphasizes the mastery of professional skills of graduates and the coordinating and handling of events; the expert capacity require graduates to have a higher level of self-study ability [19].

Accordingly, based on the professional practice competency standards of international quantity surveyors association and literature studies, this study constructs the evaluation index system of graduate employability in application-oriented cost engineering, and test it preliminarily combined with the expert-group discussion. The research group will firstly send the index system of graduates' employability in cost engineering to the expert group for review, the expert group consists of 5 people, including 3 professors with rich teaching experiencing in the field of cost engineering and 3 specialists working in the field of cost engineering. Each group member independently supplies the employment capacity not mentioned in the list, and delete the element he/she think not important, repeating this by three times. To ensure the feasibility and the operation of the model behind, this study classifies the elements of employability, then merges and reconstructs them. Eventually, we obtain 16 evaluation indicators of employability in application-oriented cost engineering, and integrate them into four dimension: professional capacity, learning capacity, communication skills and professionalism, as shown in table 2 below.

Table 2 The initial evaluation index system of graduates' employability in application-oriented cost engineering

\begin{tabular}{lll}
\hline \multicolumn{1}{c}{ Dimensions } & \multicolumn{1}{c}{ Explicit index } & \multicolumn{1}{c}{ Literature sources } \\
\hline \multirow{3}{*}{ Professional competence } & C11 Project valuation & Chen, Wang, PAQS , RICS \\
& C12 Bid management & Xiong, Wang, PAQS, RICS \\
& C13 Contract management skills & Xiong, Wang, PAQS, RICS \\
\hline \multirow{5}{*}{ Learning ability } & C21 Ability to use software & Luo, Ronald, Colin \\
& C22 Adaptability & AIQS, Law, Wong, Mobley \\
& C23 Self positioning capabilities & Fugate, Luo \\
& C24 The access to information & PAQS, Basket \\
\hline \multirow{5}{*}{ Communication skills } & C31 Conflict management skills & Luo \\
& C32 Interpersonal communication skills & Hillage, Pollard, AIQS \\
& C33 Reading and writing ability & RICS,PAQS \\
& C34 Organization and coordination ability & Wang Yi, PAQS \\
\hline & C41 Professional ethics & Law, Wong, Mobley \\
& C42 Code of conduct & Fugat, Ronald, Colin \\
& C43 Enterprising spirit & RICS, PAQS \\
& C44 Responsibility & Li, Liu \\
& C45 Team cooperation & Hillage Pollard, Luo, AIQS \\
\hline
\end{tabular}

\section{Conclusion}

“The Accreditation in Engineering Education (Draft)” promulgated by The Chinese Ministry of Education provides a common criteria for engineering education of undergraduate, but the industry 
association doesn't establish the specific standard, namely the competence standards system. Only "the Basic Requirements for the Cultivation of the Capability of Cost Member (Draft)" summarizes the capability of cost member as ideological and moral demands, professional knowledge, sports requirement, development capacity and other requirements. To a certain extent, it also confuses the concept of knowledge training and capability training. Taking the cost engineering as an example, this study defines the index system of employability through the qualitative literature analysis and the expert-group discussion. The results show the index system built before can explain the connotation of graduates' employability better, providing the competency standards available for reference to ensure that graduates can adapt the social and industry demands better.

\section{References}

[1] G.F. Zhu, Current status and prospects of engineering education in China, J. Research in Higher Education of Engineering. 6 (2011) 1-4.

[2] Y. Cao, Building the framework of China's modern vocational education system, J. Research in Educational Development. 11(2013) 41-45.

[3] X.H. Chen, Z.J. Wu, J.Q. Li, The research on characteristics and development of new application-oriented colleges, J. China University Teaching. 6(2010) 4-6.

[4] C. Overtoom, Employability Skills: An Update [EB/OL]. http://www.brown fields-toolbox.org/ files/employability_skills. Pdf 2010.

[5] J. Hillage, E. Pollard, Employability: developing a framework for policy analysis [EB/OL].http://www.employmentstudies.co.uk/summary/summary.php?id=emplblty, 2008-02-22.

[6] M. Fugate, A.J. Kinicki, A dispositional approach to employability: development of a measure and test of implications for employee reactions to organizational change, J. Journal of Occupational\& Organizational Psychology, 81, 3(2008) 503 -527.

[7] S.Y. Xiong, D.J. Huang, The research on university students' employment and training ability of employment, J. Journal of Chongqing Polytechnic College. 2(2005) 107-110.

[8] J.B. Huang, Higher education system and the employment of university graduates, J. Jiangsu Higher Education. 1(2007) 72-74.

[9] Z. Luo, P. Fang, et al., The theoretical structure of Chinese college students' employability, J. Psychological Exploration. 1(2010) 74-77.

[10]Z. Tan, The analysis of the conception of college students' employability, J. Jiangsu Higher Education. 4(2010) 81-82

[11]X.P. Zhu, The discussion of the cultivation of college students' employability, J. Higher Education Exploration. 4(2009) 124-127.

[12]P. Knight, M. Yorke, Learning, curriculum and employability in higher education, Routledge, London, 2004.

[13]CMVD Heijde, Beatrice I. J. M. Van der Heijden, A competence-based and multi-dimensional operationalization and measurement of employability, J. Human Resource Management. 3(2006) 449-476.

[14]W.X. Lu, The predicaments and transcendence of life-long education of high skilled talents_ from the perspective of the cohesion of application-oriented undergraduate and higher vocational college, J. Heilongjiang Researches on Higher Education. 1(2012) 91-94.

[15]RICS. Requirements and competencies [EB/OL]. http://www.rics.org/site/down-load_feed.aspx?fileID=3729\&fileExtension=PDF, 2012-10-15. 
[16]PAQS. Competency standards for quantity surveyors in the asia-pacific region [EB/OL].http://paqs.net/index.php?option=com_docman\&task=cat_view\&gid=39\&Itemid=11, 2012-09-15.

[17]AIQS. Precis of national competency standards for quantity surveyors [EB/OL].http://members.aiqs.com.au/iMISpublic/Core/Orders/product.aspx?catid=11\&prodid= 17, 2011-06-15.

[18]L. Yan, Y.L. Yin, The research on professional certification of application-oriented undergraduate, Tsinghua University Press, Beijing, 2013.

[19]L. Yan, Y.J. Zhang, Research on the construction of competence standards under the double certificate accreditation mode, J. Science \& Technology Progress and Policy. 23(2013) 120-125. 